\title{
EX-POST EVALUATION OF THE CONSTRUCTION OF A NEW DESALINATION PLANT AND ENLARGEMENT OF AN EXISTING DESALINATION PLANT IN ÁGUILAS, MURCIA, SPAIN
}

\author{
ARMANDO ORTUÑO PADILLA, MARÍA DEL MAR MORENO \& JAIRO CASARES \\ University Institute of the Water and the Environmental Sciences, University of Alicante, Spain
}

\begin{abstract}
This paper illustrates the main results of work in progress for a project that has been funded by the European Commission. Under the supervision of CSIL (Centre for Industrial Studies), it reports the story of the construction of the new desalination plant in Águilas/enlargement of Águilas desalination plant, a project co-financed by the European Union during the programming period 2000-2006. More specifically, this is an ex-post evaluation assessing the long-term effects produced by the investment and aimed at understanding the mechanisms and determinants likely to have contributed to produce these effects. The analysis draws on an ex-post cost-benefit analysis and an extensive set of qualitative evidence, both secondary (official reports, press articles, books and research papers) and primary (site visits and interviews with key stakeholders and experts that were carried out in October and November 2018). The project is considered to be successful overall as it achieved its intended primary objectives. The cost of desalinated water produced by the new plant was $€ 325,274$ per cubic hectometer in 2017 . When considering its impact on the served population, the final assessment is unambiguously positive, given the measurable effects on employment, diversification of traditional crops and boosting agriculture technology in the area. Besides these effects, interviews with local stakeholders have revealed that additional, complementary water-saving investments are planned on infrastructure for water storage and irrigation modernization as a consequence of this project implementation, assuring the sustainability of this investment for future generations in the Alto Guadalentín county.

Keywords: desalination plant, desalinated water, cost-benefit analysis, drought, Spanish river basins, European Union, environmental effects, agriculture, economic growth, aquifer.
\end{abstract}

\section{INTRODUCTION}

The major project "New desalination plant in Águilas/Guadalentín/Enlargement of Águilas desalination plant" addresses the need to ensure the necessary water resources for agricultural production in the area of Águilas and Alto de Guadalentín as well as urban supply, regardless of the weather conditions. This project consists in the construction of Águilas/Guadalentín desalination plant, with a capacity of $60 \mathrm{hm}^{3} /$ year (extendible to $70 \mathrm{hm}^{3} /$ year), and enlargement of the existing Águilas farmers' committee desalination plant to allow a capacity expansion.

Before the project implementation, water sources in the area of Águilas and Alto Guadalentín were in deficit due to the lack of rainfall and the overexploitation of the aquifer caused by the high volume of groundwater supplied for agricultural purposes [1]. Moreover, this situation was exacerbated by the lack of guarantees in consignments from the TajoSegura transfer. The scarcity of water resources affects not only the more dynamic and export-oriented crops, but also to the agri-food industry linked to them. In order to satisfy the water needs of agricultural production, many hydraulic infrastructures have been constructed throughout the years, the most relevant being the Tagus-Segura aqueduct, which regulates and transports surface water resources of the Segura river and other basins.

Despite the existence of those infrastructures, water demand associated to agricultural production and over-exploitation of Alto del Guadalentín aquifer, required the creation of 
new projects, such as the Águilas desalination plant. Because the transfers are strongly influenced by the hydrological situation in the headwaters of the donor basin, there were severe yearly fluctuations. Despite the rainfall deficit, the geographical situation makes irrigation highly needed in this area, because it is an important agricultural production hub, contributing to the $29 \%$ of the employment in this area [2], [3].

The major project under assessment, responds to intervention needs in the water cycle as indicated in the Axis 3 of the Operational Programme (OP) of the Autonomous Community of Murcia [4], where it remains expressed, among other actions, the need to carry out infrastructure aimed at the generation of water resources to supply water, even in long periods of drought, to the population and to the economic activities of the region. Among the infrastructure necessary indicated in measure 3.1 of the OP of Murcia, the possibility of use seawater desalination systems, considered a source of appropriate supply to guarantee the availability of resources for urban and agricultural use.

Likewise, the use of desalination to capture new water resources, translates into a decrease in the volume of groundwater extraction. This allows the mitigation of the risk of exhausting the aquifers and maintain a good level of subterranean water quality.

The project was part of the A.G.U.A. Programme ("Actions for the Management and Use of Water") of the Ministry of Environment, whose strategy is to carry out a set of concrete actions designed to guarantee the quality and availability of water. In this sense, the application of desalination technologies is considered of great importance to achieve the intended objectives.

The various actions entrusted to ACUAMED (Aguas de las Cuencas Mediterráneas (Mediterranean Basins' Waters)) are collected under the Royal Decree Law 2/2004, today Law 11/2005, and contained in the A.G.U.A. Programme [5].

At the current moment, the new desalination plant is a facility built with an annual capacity of $60 \mathrm{hm}^{3}$, including civil works needed for a future enlargement up to $70 \mathrm{hm}^{3}$. The present water supply reaches $56 \mathrm{hm}^{3}$, which means that it is operating at a full technical production capacity.

The original supply objectives were $10 \mathrm{hm}^{3}$ for domestic consumption and $50 \mathrm{hm}^{3}$ for agricultural purposes for the area of High and Medium Guadalentín as well as the coastal area of the Águilas municipality [1].

These are maximum volumes, but ACUAMED experts explained that maximum real production of desalination plant is around $56 \mathrm{hm}^{3}$ per year. This is due to maintenance works which interrupt the production twice a year. Furthermore, according to the agreements with end-users, the IC of Águilas was demanding up to $15 \mathrm{hm}^{3} /$ year; IC Lorca up to $20 \mathrm{hm}^{3} /$ year; IC Puerto Lumbreras up to $5 \mathrm{hm}^{3} /$ year, IC Pulpí up to $5 \mathrm{hm}^{3} /$ year: totalling $45 \mathrm{hm}^{3} /$ year for irrigation purposes. Any increase in the use of water over this agreements (reassigned) is out of convention and therefore is paid at a higher price. This supplementary water is "regulated" regarding the overlapping volume for urban water that in principle corresponds to the "Mancomunidad de Canales del Taibilla" [6]. In this case, although they are reserved up to $10 \mathrm{hm}^{3}$ theoretically, in 2017 they only used $1.3 \mathrm{hm}^{3}$. In the medium term the consumption of the community is expected to rise at $5 \mathrm{hm}^{3} /$ year because some of the "Mancomunidad de Canales del Taibilla" water resources will diminish. This means that $5 \mathrm{hm}^{3} /$ year could be "reassigned" to the Irrigation Communities.

Since May 2015 the Drought Law was declared for the Segura Basin, and therefore some flexible measures to the initial allocations for human consumption were taken in order to avoid the social and economic disruptions of water deficits on agricultural production. For that reason, the initial allocations of $10 \mathrm{hm}^{3}$ were made available in case of urgency, to agricultural use, which has been happening since that date. 
The most significant aspect, common to all the irrigation areas of influence, is the decrease of river transfers in favour of a remarkable use of the desalination plant, despite the cost increase for users of this kind of water. According to the interviews carried out during the case study evaluation, final users would value more the presence of a constant available water source for irrigation that makes economic planning feasible for their activities, rather than a cheaper source with a lower price but with a high uncertainty in its accessibility.

\section{DESCRIPTION OF MAIN EFFECTS OF THE PROJECT}

The European Union makes investment decisions based on verifiable methods. In this sense, European Commission has provided the "Guide to Cost-Benefit Analysis of Investment Projects" [7], providing a framework of analysis to identify the most crucial aspects of the project's performance and final outcome. The cost-benefit analysis (CBA) is an appropriate analytical approach for the evaluation because it can provide quantification and monetarisation of some of the long-term effects produced by the project. The CBA Guide [7] states that European financial support should be provided when the project is not sustainable from a financial point of view but generates important socioeconomic and environmental benefits in the area, enough to support the project with European funding. In these cases, the economic appraisal of CBA is positive. In this project, "New Desalination Plant in Águilas/ Enlargement of Águilas Desalination Plant" was initially under this scenario, which requires external funding due to it was not financially sustainable, so European Union supported the project with a grant of $€ 47.88$ million (in nominal terms), representing $19.13 \%$ of the project final cost, $€ 250.08$ million (nominal).

Actually, five years after the project started the operation, the European Commission had ordered an ex-post CBA complemented by qualitative techniques (interviews, surveys, searches of government and newspaper archives, etc.) in order to evaluate the performance of the Águilas new desalination plant in the coastal area of Águilas and Alto Guadalentín county.

Ex-post analysis is carried out comparing the "with-the-project" and "without-theproject" scenarios in the area of study. In order to determine the effects generated by the project, first of all it is necessary to establish the demand of water in the area of Águilas and Alto Guadalentín county, as well as supply provided in both scenarios, including the in CBA only the difference between them.

Regarding water demand in the area of the project, according to the Hydrographic Plan of Confederation of Segura Basin 2015-2021 [1], water demand in the agricultural area of Águilas and Alto Guadalentín stands at $159 \mathrm{hm}^{3} /$ year, including the demand of Lorca (91.5 $\mathrm{hm}^{3} /$ year), Pulpí (30 $\mathrm{hm}^{3} /$ year), Águilas ( $28 \mathrm{hm}^{3} /$ year) and Puerto Lumbreras $\left(9.5 \mathrm{hm}^{3} /\right.$ year). On the other hand, urban water demand is covered and managed by the national authority "Mancomunidad de los Canales del Taibilla" or "MCT". Actually, MCT urban water demand supplied by Águilas desalination plant is not significant $\left(1.3 \mathrm{hm}^{3}\right.$ in the year 2017), but interviewed experts of ACUAMED ensure that demand will grow to $5 \mathrm{hm}^{3} /$ year in the medium term because some of the MCT water resources will diminish, such as transfer from river Tagus-Segura due to restrictions imposed by source basins. The addition of urban and irrigation water demand results in $164 \mathrm{hm}^{3} /$ year.

For the "without-the-project" supply, the assumption has been made using a "businessas-usual" scenario. Historical and future water consumption of farmers' committees has been made from existing water sources before Águilas desalination plant operation, that is, aquifer water maximum production avoiding over-exploitation, existing Águilas farmers' committee desalination plant production, and transfer of river Tagus-Segura and Negratín-Almanzora. 
Using the assumptions mentioned above, the maximum supply of water on "without-theproject" scenario is $84.35 \mathrm{hm}^{3} /$ year.

For "with-the-project" supply, ACUAMED experts explained in interviews that due to maintenance works, the desalination plant requires yearly two technical stops that reduce the theoretical maximum production of $60 \mathrm{hm}^{3} /$ year. So, on the basis of 2017 production volume - the first year operating at full capacity - we assume a maximum production of $56 \mathrm{hm}^{3} /$ year during the forecast period. Furthermore, we assume that under the "with-the-project" scenario aquifer production is limited to the minimum required volume in the farmers' committees where desalination water supply has allowed to cover total water demand. Moreover, in this "with-the-project" scenario, the urban water required by the national authority "Mancomunidad de los Canales del Taibilla" in the medium term ( $5 \mathrm{hm}^{3} /$ year) will be totally covered by the water production of Águilas desalination plant. Using this assumptions, the maximum supply of water on "without-the-project" scenario is $134.80 \mathrm{hm}^{3} /$ year. As can be seen, neither scenarios cover total demand of $164 \mathrm{hm}^{3} /$ year required in the area of the project. However, the "with-the-project" scenario supply is close to covering the total demand $(82.90 \%)$.

An in depth analysis of the previous results regarding the "with-the-project" scenario and carried out by farmers' committees information provided shows that the "with-the-project" scenario covers total water demand of Águilas and Pulpí farmers' committees, and most of Puerto Lumbreras farmers' committee demand, supplying a volume of $8.5 \mathrm{hm}^{3} /$ year of $9.5 \mathrm{hm}^{3} /$ year demand $(89.50 \%)$. In addition, water supplied to Lorca farmers' committee grows until $65.30 \mathrm{hm}^{3} /$ year, although still it is far from $91.5 \mathrm{hm}^{3} /$ year demand $(71.40 \%)$, in total $82.90 \%$ of the total demand as noted above.

Once explained the increase of water sources due to the Águilas new desalination plant and the enlargement of existing Águilas farmers' committee desalination plant, the effects provided for this project are presented below.

\subsection{Effects related to economic growth}

One of the most important effects of this project is the increase of amount of water supplied due to the operation of Águilas desalination plant, with a real production of $56 \mathrm{hm}^{3}$ per year. The effect has been valued considering the incremental profit of the incremental agricultural production allowed by the project. The expansion of the water supply led to an expansion of the irrigated areas, which in turn led to an increase in the agricultural turnover. According to the Hydrographic Plan of Confederation of Segura Basin 2015-2021 [1] and farmers' committee information, total hectares of irrigated land (50,000 hectares) and water demand $\left(159 \mathrm{hm}^{3} /\right.$ year) to fill these areas have been obtained. Using historical and forecast water supply of the "with-the-project" scenario and the "without-the-project" scenario, it has been established the number of irrigated hectares of land in each scenario in the area of Águilas and Alto del Guadalentín.

Also, the availability of high-quality desalinated water allowed plantations of new crops of higher added value (for example, table grapes) not cultivated before, in areas like Águilas where the best option was tomato (which is a crop of lower price and very sensitive to imports from non-EU countries). Therefore, farmers' appraisal of the improvement of the water quality is very positive because the use of desalinated water has avoided infiltration of brackish water in the soil (the one of aquifers), and this is helpful, since soils irrigated with high salinity waters are at risk of being lost and irrecoverable. From the point of view of the brine, the impact it generates in the sea is much less than the fact that salty water from aquifers continues to be added to the subsoil and agricultural land. 
The benefits of increased water supply and increased water quality have been jointly estimated considering the incremental net profit generated in the catchment area thanks to the project.

Using the incremental number of irrigated hectares, the net profit production value per irrigated hectare provided for Hydrographic Plan of Confederation of Segura Basin (for each farmers' committee area) and applying a reduction factor of 0.8 for prudency reasons the socioeconomic benefits related to economic growth over the entire time horizon of the project is estimated at $€ 1,331.8$ million (discounted by rates of $3.87 \%$ backward and $4.15 \%$ forward).

On the other hand, also the improvement of the reliability of water sources and water supply has been taken into account. The most successful advantage of the new desalination plant for Irrigation Communities is the fact of having a constant new water source, not dependent on policy measures such as the Tagus-Segura transfer. The impact on employment of such infrastructure is considerable. According to the information provided by the Irrigation Communities and the Regional Statistics Office [3], the availability of a permanent source of fresh water has allowed better planning of crops, has assured the maintenance of international commercial contracts with main export destinies and consequently, has increased employment in the area of influence. In this sense, the employment in agriculture in the area of influence of the new desalination plant has increased by $66.9 \%$ between 2013 (first year of operation) and 2017.

Additionally, observing the main parameters that characterize specifically the area of study in Alto Guadalentín, water scarcity is a serious threat to sustain the local economy model. Therefore the project was seen as very favorable because it supported the needs to maintain agriculture, as one of the pillars of the economic activity in the agricultural fields of Águilas, Lorca and Puerto Lumbreras, as well as to preserve natural environments. A brief overview on the main labour force statistics of last year in the study area, shows that employment in the agriculture sector represents more than double the Murcia regional average with $12.8 \%$ in 2017 , and more than $80 \%$ in the case of Pulpí.

\subsection{Effects on environmental sustainability}

Related to environmental sustainability, another measurable benefit, that has been included in the ex-post CBA, is related to avoiding overexploitation of the aquifer Alto Guadalentín by decreasing the use of groundwater for irrigation, thus, improving the aquifer status and reducing pollution. Years of excessive use of groundwater for irrigation has had a negative environmental effect on the quality of this water, because of a decrease in the water quantity and a concentration of nitrates, salt and nutrients. This was particularly serious in the case of the Irrigation Community of Águilas, where the main aquifer was not usable anymore and led them to build the first desalination plant.

Before the project implementation, there was an intensive use of aquifers for irrigation that led to the degradation of groundwater quality and quantity, which made it not to usable for agricultural activities. The Framework Directive on Water and Groundwater 2000/60/EC [8] makes clear the way forward in the case of overexploitation of aquifers: "all those bodies of water that in 2027 do not reach optimum levels of exploitation must be closed". In other words, the overexploited aquifers of the Segura basin had to cease, unless new fresh water would have increased the quantity of available water in the territory. This could only occur either in the form of constant rainfall that recharges them naturally, which is not the climate condition of this territory (the yearly average rainfall in 2017 was $1601 / \mathrm{m}^{2}$ in Alto Guadalentín, compared to $474 \mathrm{l} / \mathrm{m}^{2}$ Spanish average), or, in the form of policy agreements, that bring supplementary resources from outside the basin and allow farmers to stop using 
the exhausted aquifers. However, due to the different political positions between regional and national administrations in Spain, the water transfers are difficult and therefore, desalinated water is the most reliable option to guarantee a constant water source in Alto Guadalentín.

At present, groundwater for irrigation is mostly used to mix with desalinated water, improving nutrients and complementing quality for irrigation. This new water is producing an induced aquifer recharge through infiltration by irrigation in the territory, preserving soil moisture and vegetation.

In order to quantify the impact of the improvement of the aquifer, this effect has been valued using the value transfer method. In particular, the non-use value for environmental improvement of the aquifer had been obtained from a study carried out in the aquifer of Caravaca de la Cruz municipality, located in the Region of Murcia and into the boundaries of the Segura river basin [9], valued at $€ 69,538$ per cubic hectometre. The environmental benefit of aquifer preservation over the entire time horizon of the project is estimated at $€ 9.1$ million (discounted by rates of $3.87 \%$ backward and $4.15 \%$ forward).

In a different manner, the effect in climate change resilience should be taken into account in this analysis although it is non-measurable. Climate change is affecting cultivation conditions that are specific of a certain kind of crop variety (temperature, moisture, water), so a new water resource, such as desalinated water, will help to improve agricultural production. This allows and encourages new investments in R\&D for crop resistance and the introduction in the area of study of enhanced greenhouses that use monitored dropping systems. These systems need the best water quality, in order to avoid dripper obstructions and usually include osmosis plants. Therefore, using desalination water contributes to improve the quality of water, which has a direct influence on resilience of the environment, in particular soil and crop production.

\subsection{Other effects considered}

The positive effect on quality of life and well-being reported has been considered as an indirect consequence of economic growth and employment in the area. This effect has been revealed in all municipalities that the project has served. As has been informed by the interviewees, before the project implementation there were territories of land not cultivated in previous years that have entered in production thanks to the availability of water. This means, new investments in the territory (construction of dams and irrigation modernisation), the increase of production capacity, new incomes for the farmers and the development of a complementary industry and services in the territory.

Besides open field cultivation, the Alto Guadalentín area is characterized by an increasing use of greenhouses, in particular in the area of Águilas. The availability of higher quality water has incentivised farmers to invest in more enhanced greenhouses, using monitoring of irrigation and implementing eco-innovation actions to save water and energy through investment of highly efficient greenhouses. Achieving a switch from conventional to a more efficient greenhouse (in terms of water, energy and other resources) is a priority for a sustainable agriculture in the territory of study.

Also, the project has had a positive effect on territorial cohesion through retaining population in the territory, and, increasing economic activities and investments. The project has contributed to local development by boosting local industries, taking advantage of territorial strengths and potentialities to develop a sustainable agriculture and improve water management of Irrigation Communities. 


\subsection{Results of socioeconomic analysis}

From the beginning of operation phase, Águilas desalination plant has been converted in a strategic infrastructure for economic development of the region, taking into account that farming is the most important economic activity in Águilas and Alto del Guadalentín area. According to estimations of Hydrographic Plan of Confederation of Segura Basin 20152021, water demand will remain stable in future years as a result the mentioned effects shall continue until the end of analysis period.

This project has been successful in meeting water demand for Águilas and Pulpí farmers' committees and has increased available water sources for Lorca and Puerto Lumbreras farmers' committees, reducing the supply provided by the aquifer to the minimum. Moreover, the reliable new water supply, has enabled farmers to increase the irrigated area and crop production, once initial hesitation in using desalinated water has been overcome, thus increasing obtained benefits. Furthermore, the availability of guaranteed resources has enabled farmers to invest in improving water resource management.

The results of the economic appraisal of CBA indicate that the project adds value to the European society from a social and economic point of view. In the baseline case, the SocioEconomic Net Present Value (ENPV) equals $€ 711.8$ million, whereas the Economic Internal Rate of Return is at the level of $12.5 \%$. Also, the risk analysis indicates that overall the CBA outputs are robust to possible variations in the key variables. Moreover, the benefit-cost ratio, valued at shadow prices, is equal to 2.78 , proving a positive quantitative impact of the project for society.

\section{MAIN RESULTS AND LESSONS LEARNED}

Based on the different findings produced by the project analysis both in terms of effects generated and measured through the CBA or qualitatively discussed as well as of factors affecting the generation of those effects, the final assessment of the project performance is presented below.

Regarding the project relevance and coherence, the project was highly relevant in the context where it was implemented and matched a real and urgent need, providing a long-term solution to the serious water management problems that were affecting the Alto Guadalentín county in the Region of Murcia. Since the project was designed in order to provide a permanent new fresh water source to the fields, the project is expected to remain relevant also in the future.

The project was in line with the strategic priorities set at various levels (European, national and regional). It represented a necessary and important step to avoid over-exploitation of aquifers and environmental degradation. In this respect, the project was consistent with the European Water Framework Directive (2000/60/EC) and the Drinking Water Directive (1998/83/EC) [8], and with the goals set out in the ERDF Region of Murcia Operational Programme 2000-2006, Axis 3, measure 3.1. "Water supply to citizens and business". The project has been classified as "Priority and urgent interventions" by the National Hydrological Plan [10].

At the same time, the new plant was in line with the national goals of Programme A.G.U.A. (2004-2008) drafted by the Ministry of Environment aimed at improving the availability of water resources and their management. From this perspective, it is clear that the new desalination plant was necessary, but it would not be sufficient as the trend for water demand for irrigation is increasing with the availability of new water supplied by the new desalination plant. Additional investments should be put in place with respect to water storage and distribution network. 
Regarding project effectiveness, against a total initial investment cost of $€ 250.18$ million (VAT excluded) and approximate $€ 394.35$ million for annual operation and maintenance until the assumed last year of the project time horizon (2034), the project produces a net socio-economic contribution to society, measured by the economic net present value, of $€ 711.8$ million. The internal rate of return is equal to $12.5 \%$ against a benchmark social discount rate of $3.87 \%$ for the past and $4.15 \%$ for the future.

The main socio-economic benefits produced by the project are the constant and reliable provision of high-quality water for irrigation purposes as well as the elimination of aquifer overexploitation in Alto Guadalentín, as expected ex-ante and consistent with the project's objectives.

After five years since the start of the new desalination plant operational phase, the longrun contribution of the project translates into a significantly enhanced development of the catchment area.

End users do fully benefit from the project's success and new dams and water infrastructure are forecast, both by ACUAMED and by the Irrigation Communities, to take advantage of the new enlargement and to facilitate future water storage. Moreover, the provision of a new permanent source of additional high-quality water supply has produced very favourable impacts on the local economy, notably by guaranteeing the ability to sustain agricultural productions and meet international commercialisation agreements. Irrigation water is one of the main inputs sustaining growth and investment in Murcia, where currently $96 \%$ of agricultural exports are destined to EU countries.

As a conclusion of the ex-post evaluation, the project has contributed to improved water infrastructure and resource management, to achieve sustainable growth in the Region of Murcia province and in particular the project area (Águilas and Alto del Guadalentín), where irrigation water comes from groundwater as the only source. The results of the ex-post CBA confirm that the project was worth implementing from a socio-economic standpoint.

At the same time, this ex-post assessment also suggests that in order to ensure the longterm success of this project, which is mainly focussed on water for irrigation, additional investments for water storage are needed in order to lower operational costs and to ensure adequate water sources to meet the farmers' requirements. This case study gives the opportunity to draw important lessons of more general relevance.

- Support of end-users. Project implementation difficulties and delays could be overcome by prior consultations and communication with end users. The project has been successful and appropriate to the context and relevant to the objectives at local, regional and national level. As a consequence, end-users are confident on future investments of ACUAMED, to meet the current demands of water, for what an expansion of the plant capacity up to $70 \mathrm{hm}^{3} /$ year will be suitable.

- The managerial capacity of ACUAMED and the alignment of this investment with the governmental programme A.G.U.A., enabled a smooth implementation and operation of the project. High technical competence and solid managerial capacity are indeed key to ensure the project resilience at various levels.

- Synergies of the project and complementarity with other EU policies. The well-studied regional context where the project needs to be built, has facilitated that the project effectively contributes to wider impacts both in terms of economic growth and wellbeing. This is especially evident for projects that contribute to boosting natural potentialities of the territories, that in the case of the study area are the food industry, water management technologies and tourism. In these cases, the creation and stabilisation of wider impacts will create a spill-over effect, with the implementation of 
complementary investments on optimising water management conditions and networks, and on the commitment of entrepreneurial investments.

- The institutional context and legislative framework were favourable to clearly setting the share-out of responsibilities and providing incentives for committing to long-term investment plans. This project was smoothly implemented due to the favourable political context to provide solutions that ensure the fulfilment of the environmental objectives, the attention to demand requirements in the basins most vulnerable to water deficit risks within the country, compliance with political commitments and legal obligations with the European Union and the need to ensure the necessary economic-financial stability for the Spanish water system.

\section{REFERENCES}

[1] Hydrographic Plan of Confederation of Segura Basin 2015-2021. Confederation of Segura Basin, Ministry for Ecological Transition, Government of Spain. www.chsegura.es. Accessed on: 20 Feb. 2019.

[2] Statistics and Cartography Institute of Andalusia. Regional Government of Andalusia (Junta de Andalucía). www.juntadeandalucia.es/institutodeestadisticaycartografia/. Accessed on: 20 Feb. 2019.

[3] Statistics Regional Centre of Murcia. Regional Government of Murcia. http://econet.carm.es/. Accessed on: 20 Feb. 2019.

[4] European Commission, Directorate-General for Regional and Urban Policy. https:/ec.europa.eu/regional_policy/en/atlas/programmes/2000-2006/spain/objective1-programme-for-murcia. Accessed on: 20 Feb. 2019.

[5] ACUAMED Desalination in Spain. Ministry for Ecological Transition, Government of Spain. www.acuamed.es/en/publications. Accessed on: 20 Feb. 2019.

[6] Mancomunidad de Canales del Taibilla, Ministry for Ecological Transition, Government of Spain. www.mct.es. Accessed on: 20 Feb. 2019.

[7] European Commission, Directorate-General for Regional and Urban Policy, Guide to Cost-Benefit Analysis of Investment projects, Economic Appraisal Tool for Cohesion Policy 2014-2020, Publications Office of the European Union, 2014.

[8] European Commission, Directive 2000/60/EC of the European Parliament and of the Council Establishing a Framework for Community Action in the Field of Water Policy, European Union, 2000.

[9] Martinez-Paz, J.M. \& Perni, A., Environmental cost of groundwater: A contingent valuation approach. International Journal of Environmental Research, 5(3), pp. 603$612,2011$.

[10] Ministry of Environment, Spanish Hydrological Plan, Government of Spain, 2001. 